\title{
Structural responses of Ipomoea nil (L.) Roth 'Scarlet O'Hara' (Convolvulaceae) exposed to ozone
}

Bárbara Bâesso Moura ${ }^{1,2}$, Sílvia Ribeiro de Souza ${ }^{1}$ and Edenise Segala Alves ${ }^{1}$

Recebido em 6/08/2010. Aceito em 3/01/2011

\begin{abstract}
RESUMO
(Respostas estruturais em Ipomoea nil (L.) Roth 'Scarlet O'Hara' (Convolvulaceae) exposta ao ozônio). Devido à sua alta reatividade e fitotoxidez, o ozônio troposférico $\left(\mathrm{O}_{3}\right)$ é um dos mais importantes poluentes fotoquímicos, podendo provocar alterações microscópicas em plantas antes do aparecimento de sintomas visíveis. O presente estudo teve como objetivo aprimorar os conhecimentos sobre os efeitos do $\mathrm{O}_{3} \mathrm{em}$ folhas de Ipomoea nil. Plantas foram expostas na cidade de São Paulo em local com altos níveis de $\mathrm{O}_{3,}$ e também fumigadas com esse gás. Plantas, sem sintomas visíveis, expostas no ambiente, apresentaram alterações microscópicas indicativas do estresse oxidativo como resposta semelhante à de hipersensibilidade (HR-like) e presença de protrusões nas paredes celulares; na presença de sintomas visíveis, ruptura da epiderme e colapso do parênquima paliçádico e lacunoso. Os experimentos de fumigação confirmaram que tais danos microscópicos foram decorrentes do $\mathrm{O}_{3}$. Os resultados mostraram que Ipomoea nil responde ao estresse induzido pelo $\mathrm{O}_{3}$, apresentando alterações estruturais que antecedem os sintomas visíveis.
\end{abstract}

Palavras-chave: HR-like, ozônio, protrusões de parede celular, danos microscópicos

\begin{abstract}
(Structural responses of Ipomoea nil (L.) Roth cv. 'Scarlet O’Hara' (Convolvulaceae) exposed to ozone). Troposphere ozone $\left(\mathrm{O}_{3}\right)$ is an important photochemical pollutant due to its high reactivity and phytotoxicity. Plants can show microscopic damage caused by this gas before the detection of visible symptoms. The present study aimed to improve our knowledge concerning the effects of $\mathrm{O}_{3}$ on Ipomoea nil L. cv. Scarlet O'Hara leaves. Plants were exposed at a pollutant site in São Paulo city, with high levels of $\mathrm{O}_{3}$ and fumigation with $\mathrm{O}_{3}$ was also carried out. In plants exposed to the environment, without visible symptoms, hypersensitive response-like (HR-like) and protrusions in the cell walls was observed, indicating oxidative processes; in leaves with visible symptoms, there is epidermis breakdown and the palisade and spongy parenchyma collapse. Fumigation confirmed that microscopic damage occurring in the plants exposed to the environment was linked to the symptoms caused by $\mathrm{O}_{3}$. These results demonstrate that Ipomoea nil responds to stress induced by $\mathrm{O}_{3}$ with specific structural changes that precede visible symptoms.
\end{abstract}

Key words: ozone, HR-like, cell wall protrusions, microscopic damage

\section{Introduction}

The troposphere ozone $\left(\mathrm{O}_{3}\right)$ is a phytotoxic secondary pollutant of easy diffusion, being the most important, damaging, and oxidant among the photochemical pollutants (Klumpp et al. 2001; Krupa et al. 2001). It enters the leaf through stomata and immediately decays into different reactive oxygen species (ROS), leading to an oxidative burst which might be related to the formation of lesion points as observed in sensitive species (GünthardtGoerg \& Vollenweider 2007). Also, ROS might accumulate in the subcellular compartments of palisade cells, reacting with the lipid membranes towards the initial oxidative stress, damaging proteins and leading to a physiological deficiency (Schraudner et al. 1997). Finally, ROS cause a fast and localized cell death, characterized by cell collapse, an incomplete degradation of the cellular components and a subtle loss of membrane integrity (Günthardt-Goerg et al. 1997). According to Günthardt-Goerg \& Vollenweider (2007) such effects not only have come out by ozone stress but preferably by pathogen-induced response. So, the induction of plant defense reactions triggered by ozone stress is similar to those induced by pathogens (Rao et al. 2000; Sandermann et al. 1998). Such reactions include the induction of polyphenols, pathogenesis related proteins

1 Instituto de Botânica de São Paulo, São Paulo, SP, Brazil

2 Author for correspondence: bmourabio@gmail.com 
(PR1), cell wall modifications and localized cell collapse and death, which are indicative of programmed cell death (PCD) described as hypersensitive response (HR), which occurs in a discrete groups of cells (Niderman et al. 1995). This kind of response can be recognized by structural changes indicated by microscopic analysis in which the stress response can be seen before any visible damage (Günthardt-Goerg \& Vollenweider 2007).

Ipomoea nil L. 'Scarlet O'Hara' is well-known as sensitive to $\mathrm{O}_{3}$ (Nouchi \& Aoki 1979; Nouchi \& Toyama 1988); it presented visible symptoms when submitted to high levels of $\mathrm{O}_{3}$ (Domingos et al. 1998). Since visible symptoms are preceded by microscopic changes (Vollenweider et al. 2003), we hypothesized that Ipomoea nil exposed to ozone might manifest structural responses being useful to validate the stress induced by $\mathrm{O}_{3}$. We also aimed to improve the knowledge about Ipomoea nil, describing and comparing the microscopic damages in leaves with and without visible symptoms exposed to controlled $\mathrm{O}_{3}$ levels and at a polluted site in São Paulo city.

\section{Materials and methods}

\section{Plant growth}

Seeds of Ipomoea nil were acquired from a commercial supplier (CN Seeds LTD, www.cnseeds.co.uk). A mixture based on Pinus bark (Plantimax-Eucatex ${ }^{\mathrm{mi}}$ ) and thin vermiculite (3:1) was used as the germination substrate. The seedlings developed in transparent plastic boxes (gerbox) until the emergence of the second cotyledonal leaf, when they were transferred to $2 \mathrm{dm}^{3}$ plastic pots containing the same substrate.

The plants were irrigated by capillarity according to ISO 3957/6 (VDI 2003). All these plants received $100 \mathrm{ml}$ Hoagland nutrition solution, as described in Epstein (1975), weekly, from the transfer to the end of the experiment.

From germination to in situ exposures, the plants were kept in a greenhouse, with filter system for particles and gas pollutants and equipped with air conditioning for temperature control. The greenhouse is located at the Botanical Institute of São Paulo, which is situated in the southeast region of São Paulo city $\left(23^{\circ} 38^{\prime} 08^{\prime \prime} S\right.$ and $46^{\circ} 38^{\prime} 00^{\prime \prime} \mathrm{W}$, Fernandes et al. 2002) and was used throughout the experiment as the reference mark for visible and structural symptoms.

The plants were kept under average relative humidity of $66 \%$ during the winter and of $72 \%$ in the spring; the average temperature was $22^{\circ} \mathrm{C}$ in the winter and $28^{\circ} \mathrm{C}$ in the spring, this way simulating the conditions observed in the outdoor environment.

\section{In situ exposure}

Ipomoea nil was exposure when the fifth, sixth, and seventh leaves were well-developed, about one month after sowing. The plants were exposed in the city of São Paulo-

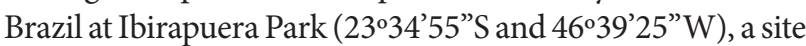
submitted to high levels of $\mathrm{O}_{3}$ (Environmental Company of São Paulo State - CETESB 2009). During the experimental period, the plants also had adequate irrigation guaranteed by capillarity through nylon strings and received periodic fertilization with Hoagland nutrition solution (Epstein, 1975).

Two exposures were carried out, one in the winter (25 August to 22 September 2006) and the other in the spring (14 November to 11 December 2006) and, in each experiment, 12 pots stayed at the Ibirapuera Park while other 12 pots were kept in the greenhouse with filters to gases and particles - Purafil ${ }^{\mathrm{Tm}}$. Samples of the leaves 5, 6, and 7 (from the plant base) were collected weekly, according to the methodology suggested by VDI (2003), from three individuals, guaranteeing that samples were taken throughout the exposure period.

$\mathrm{O}_{3}$ concentration ( $\mathrm{ppb}$ ) was constantly measured at Ibirapuera Park by CETESB as was some meteorological data (e.g. temperature, relativity humid and global solar radiation).

\section{Fumigation experiment}

The experiment were performed in closed chambers with dimensions of $85 \times 94 \times 85 \mathrm{~cm}(\mathrm{~W} \times \mathrm{D} \times \mathrm{H})$ that were composed of a stainless steel structure connected to an apparatus to humidify and mix the air, covered by a film of Teflon ${ }^{\mathrm{Tm}}$. Artificial light was supply by $400 \mathrm{~W}$ metallic vapor lamps and $30 \mathrm{~W}$ fluorescent lamps. $\mathrm{O}_{3}$ used for fumigation was produced by the dissociation of oxygen under an electrical discharge generator (Ozontechnik) as described by Souza and Pagliuso (2008). Input $\mathrm{O}_{3}$ levels were continuously measured with an Ecotech ${ }^{\text {tw }} 9810 \mathrm{~B} \mathrm{O}_{3}$ monitor and the chambers received equivalent fluxes of air during the fumigation.

Two sets with six plants each were used in this experiment. Each set was placed inside different chambers simultaneously, with continuous flow $\left(25 \mathrm{dm}^{3} \mathrm{~min}^{-1} 1 / \mathrm{min}\right)$ for six hours per day during six days. One set received only filtered air (CF) and the other filtered air added with 40 $\mathrm{ppb} \mathrm{O}_{3}$, in the first exposure and $80 \mathrm{ppb}_{3}$ in the second exposure $\left(\mathrm{CF}+\mathrm{O}_{3}\right)$. Samples of leaves 5,6 , and 7 from three individuals exposed to the different situations describe above were collected.

\section{Visible symptoms}

Leaves' visible symptoms were classified according to Krupa (2001) both on fumigated plants and on field experiment. The presence of the visible symptoms was analyzed during the entire experimental period and photographed for characterization.

\section{Microscopic analysis}

Six fragments measuring around $2 \mathrm{~cm}^{2}$, randomly selected, were cut off from each leaf $(5,6$, and 7$)$ according 
to the methodology suggested by Kubínová (1994). The samples were fixed under vacuum in formaldeide, glutaldeide, acetic acid and alcohol (FGAA) according to Lersten \& Curtis (1988) and maintained in the fixative for 48 hours to be later stored in $70 \%$ ethylic alcohol.

The material was embedded in glycol methacrylate (GMA) (historesin, Leica) in accordance with the manufacturer's recommendations. The $5 \mu \mathrm{m}$ sections, obtained from Olympus (Cut 4055) rotary microtome, were stained with $0.5 \%$ toluidine blue prepared with acetate buffer $0.1 \mathrm{M}, \mathrm{pH} 4.7$ (O’Brien et al. 1964).

The observations of the leaf sections were performed on Olympus BX41-BFIII microscopy equipped with a system to capture images and semi-automatic measuring system (Image Pro-Express version 4.0.1 software, Media Cybernetics).

\section{Results}

\section{Site study}

Winter and spring $\mathrm{O}_{3}$ patterns are shown in Fig. 1. Levels of $\mathrm{O}_{3}$ were higher in winter than in spring. Some meteorological data of Ibirapuera Park during the exposure period are shown in Table 1. The plants were kept under ideal moisture conditions in both seasons and the average temperature was around $20^{\circ} \mathrm{C}$, an atypical situation concerning the historical average for winter, when temperature is normally lower. The average global radiation was also similar in both seasons. The average concentrations of NOx, $\mathrm{O}_{3}$ precursors, were higher in winter compared to spring (data not shown), which probably explains the greater formation of the pollutant in the winter.

\section{Visible and structural variations}

Plants kept in greenhouse and under filtrated air did not show any visible symptoms (Fig. 2 A). Visible injuries, characterized by intercostal bleaching, were observed on plants exposed in Ibirapuera Park in both seasons, especially in the winter (Fig. 2 B) and also on those fumigated (Fig. 2 C)

Plants maintained in greenhouse showed no damage to the parenchyma cells (Fig. $3 \mathrm{~A}$ and $\mathrm{B}$ ). On the other hand, samples collected from areas of the leaf with visible symptoms showed epidermal rupture and collapse of the parenchyma cells (Fig. $3 \mathrm{C}$ and D). Such symptoms were observed in groups of cells restricted to the areas with visible symptoms in plants exposed at Ibirapuera Park.

In the mesophyll cells of the plants exposed at Ibirapuera Park, alterations indicative of oxidative stress generated by $\mathrm{O}_{3}$ were similarly observed in leaves 5,6 , and 7 (data not shown). In plants kept in the greenhouse and exposed to filtered air no structural damages were found (Fig. 4 A and $\mathrm{B}$ ). In leaves without visible symptoms, either in the plants exposed in the winter or in the spring a collapse was observed in isolated cells of palisade parenchyma,
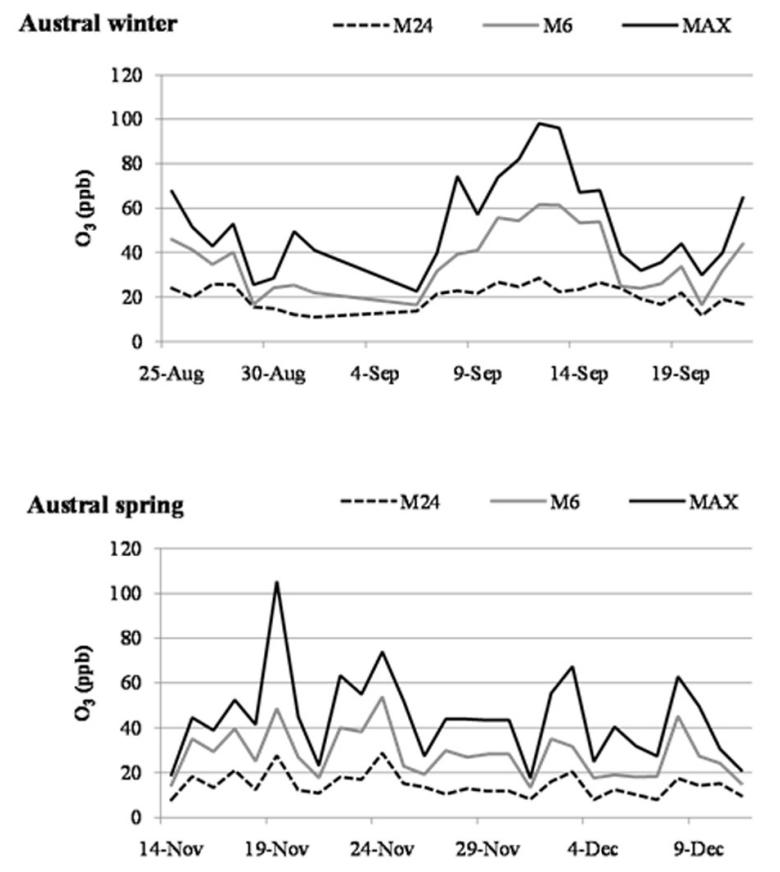

Figure 1. Daily pattern of ground-level $\mathrm{O}_{3}$ concentration (in $\mathrm{ppb}$ ) in the two time exposures (austral winter and austral spring) in 2006. M24 = mean of 24h; M6 = mean from 10:00 to 16:00; MAX = maximum daily concentration.

Table 1. Average values of environmental variables at Ibirapuera Park, during both seasons carried out in 2006. Minimum and maximum daily average values are in parentheses. T - temperature. RH - relative humidity. GR - global solar radiation.

\begin{tabular}{lcc}
\hline & Winter & Spring \\
\hline $\mathrm{T}\left({ }^{\circ} \mathrm{C}\right)$ & $19.5(13.9-24.0)$ & $21.6(19.4-25.4)$ \\
$\mathrm{RH}(\%)$ & $74(56-90)$ & $82(64-97)$ \\
$\mathrm{GR}\left(\mathrm{W} \mathrm{m}{ }^{-2}\right)$ & $352(56-488)$ & $181(77-328)$ \\
\hline
\end{tabular}

which represents a classic HR-like response, typical of $\mathrm{O}_{3}$ stress (Fig. $4 \mathrm{C}$ and D). The cell death apparently occurred quickly, since it was possible to detect the presence of chloroplasts even in the necrotic cells. Cell wall protrusions were scattered throughout the photosynthetic tissue mainly in the cells of the spongy parenchyma of plants exposed to field conditions and were not observed in plants from greenhouse (Fig. $5 \mathrm{~A}$ and B versus C-F).

\section{Structural variations fumigation}

Similarly to the plants exposed in the city of São Paulo, the fumigated plants presented symptoms characteristic of the oxidative stress induced by $\mathrm{O}_{3}$. Plants fumigated with $80 \mathrm{ppb} \mathrm{O}_{3}$ showed typical HR-like responses in the leaves, also very similar to those observed in plants exposed in São Paulo, corroborating the symptoms found in the latter (Fig. 4 E). Plants submitted to $40 \mathrm{ppb} \mathrm{O}_{3}$ did not show visible symptoms, presenting only tortuous cell walls (Fig. 4 F), especially in the palisade parenchyma. In 

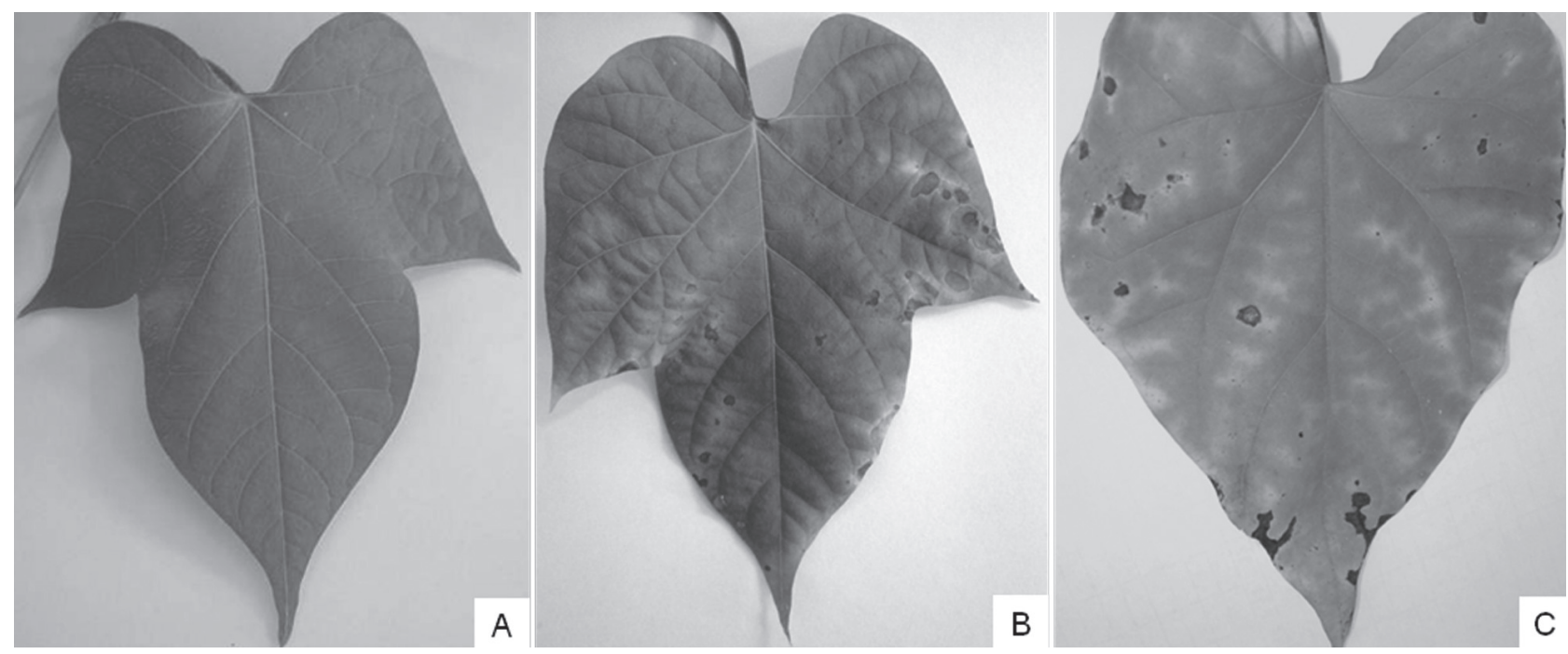

Figure 2. Leaves of Ipomoea nil. (A) Reference leaf without visible injury. (B) Visible injury (bleaching) from winter exposure. (C) Visible injury (bleaching) from fumigating experiment $\left(\mathrm{CF}+\mathrm{O}_{3}\right)+80 \mathrm{ppb}$.
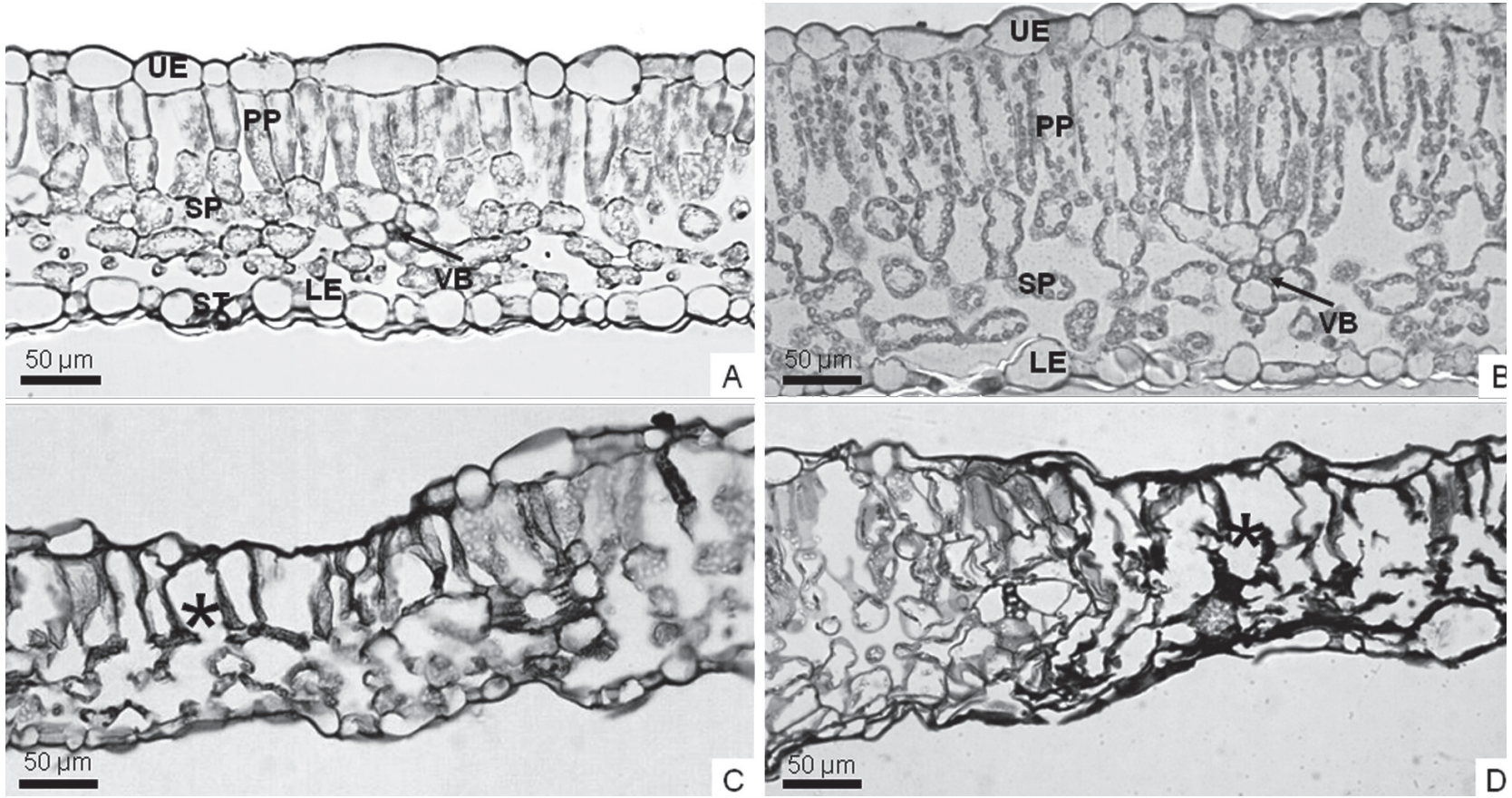

Figure 3. Cross sections of Ipomoea nil leaf. (A-B) Plants without symptoms maintained in greenhouse (A Winter, B Spring), (C-D) Plants with necroses (asterisks) maintained in Ibirapuera Park (C Winter, D Spring). UE = upper epidermis, ST = stomata, $\mathrm{PP}=$ palisade parenchyma, $\mathrm{SP}=$ spongy parenchyma, $\mathrm{VB}=$ vascular bundle, $\mathrm{LE}=$ lower epidermis.

both experiments it was not possible to find protrusions on the cell wall as those found in leaves exposed to the environment.

\section{Discussion}

According to Ferreira et al. (2007) Ipomoea nil presents an efficient antioxidant defense system which can protect plants against ozone damage and delay the visible symptoms. However in plants exposed at Ibirapuera Park, independently of the season, and those fumigated with $\mathrm{O}_{3}$, microscopic damage was observed as discrete groups of cells with remaining organelles and disrupted cell content. This kind of response was described by Günthardt-Goerg \& Vollenweider (2007), as a HR-like and it is a type of programmed cell death (PCD) and represents a plant 

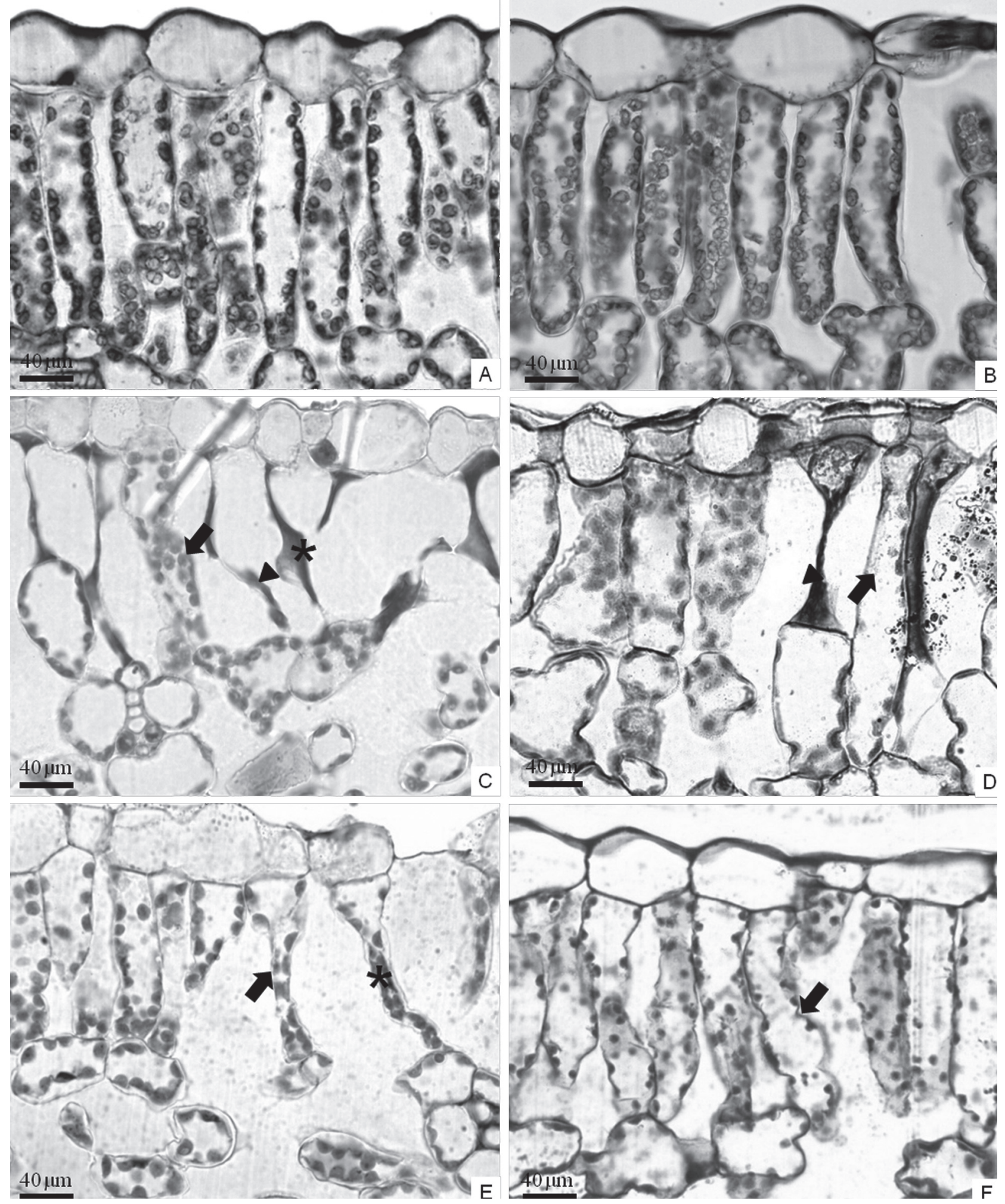

Figure 4. Cross sections of Ipomoea nil leaves. (A) Plant maintained in greenhouse without symptoms. (B) Plant maintained in chamber with filtrated air. (C and E) Plants maintained in Ibirapuera Park with a HR-like (asterisks) with remind chloroplasts (arrow) and cell-wall collapse (arrowheads) (C Winter, D Spring). (E) Plant maintained in chamber (+ $80 \mathrm{ppb})$ with HR-like (asterisks). (F) Plant maintained in chamber $(+40 \mathrm{ppb})$ with marked tortuous cell walls. 


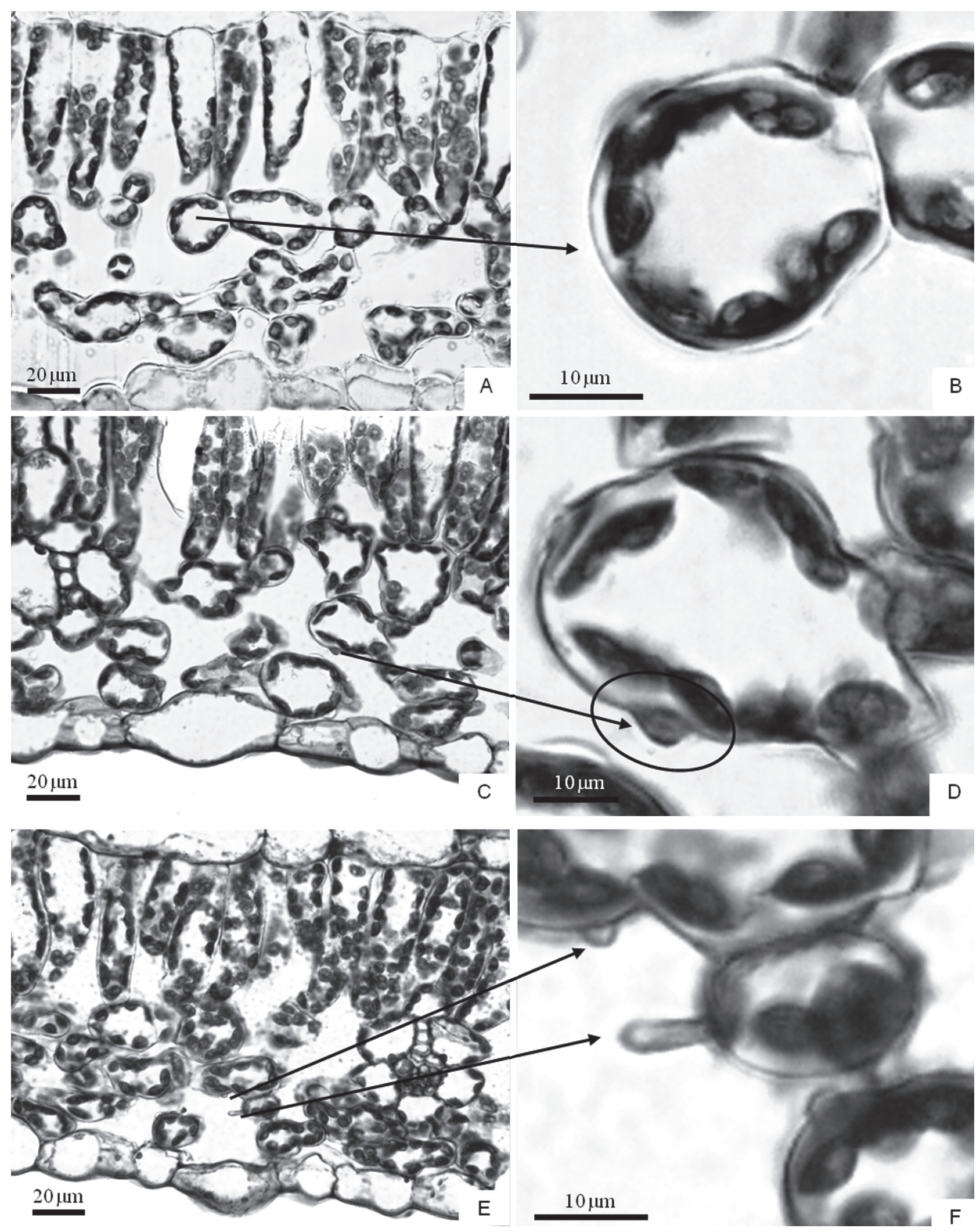

Figure 5. Cross sections of Ipomoea nil leaves. (A and B) Plants maintained in greenhouse with normal aspect of cell wall in the spongy parenchyma. (B) Detail. (C - F) Plants maintained in Ibirapuera Park with cell wall protrusions. (D and F) Detail. 
defense mechanism against biotic stress, which can also be induced by a few abiotic stress factors. The criteria to identify the HR-like response according to the same authors are the absence of pathogens, restriction of the PCD to a small group of cells, rupture of the cell contents, collapse of the cell walls, and incomplete degradation of the cell as a consequence of fast cell death. Such symptoms were observed in Ipomoea nil and turned up being very similar to the results reported by Vollenweider et al. (2003) in Robinina pseudoacacia.

According to Gravano et al. (2003), the HR-like response is normally observed in localized regions, especially in the palisade parenchyma, where it occurs in isolated groups of cells and has been used to corroborate the microscopic damage caused by $\mathrm{O}_{3}$.

In the Ipomoea nil leaves, it was also possible to observe the presence of the protrusions on the cell walls. Such protrusions occurred preferably in the spongy parenchyma cells and were evidenced only in the plants that were kept at Ibirapuera Park.

Several authors mention the presence of protrusions in plants submitted to $\mathrm{O}_{3}$. Günthardt-Goerg et al. (2000) reported the appearance of pectic protrusions and phenolic incrustations in Prunus serotina submitted to critical levels of $\mathrm{O}_{3}$. They also described the presence of cell wall invaginations in the chlorophyll parenchyma, the presence of a condensed cellular content, the cellular collapse even before the reallocation of the cellular contents and the cell death. In Pistacia lentiscus collected in an environment submitted to high $\mathrm{O}_{3}$ concentrations, Reig-Armiñana et al. (2004) described the appearance of protrusions on the cell walls of the spongy parenchyma cells and, furthermore, the degeneration of the tonoplast and consequent cellular disorganization. Günthardt-Goerg \& Vollenweider (2007) documented the appearance of HR-like responses and protrusions on the spongy parenchyma cell wall in Sambucus racemosa as a result of the oxidative stress caused by $\mathrm{O}_{3}$. The authors affirm that the microscopic alterations can be simultaneous or previous to the first visible symptoms, which is of interest, since it allows forecasting beforehand plant sensitivity to $\mathrm{O}_{3}$.

Also, no alterations were observed in the conduction tissue of Ipomoea nil, neither in the plants exposed São Paulo, nor in the fumigated plants, indicating that the symptoms induced by $\mathrm{O}_{3}$ are occurring between the vascular bundles and not over them (Novak et al. 2003) as a characteristic of the $\mathrm{O}_{3}$ stress.

Studying the leaf samples with visible symptoms of Ipomoea nil exposed at Ibirapuera Park, a necrosis through a part or all through the leaf blade was found, both in the palisade and spongy parenchyma as well as in the epidermis cells perceiving in an isolated region of the leaf. With the progressive increase of visible damage, the cells appeared empty with invaginated cell walls and condensed cell content.
In general, the symptoms observed in Ipomoea nil exposed in the city of São Paulo were the same described by the different authors herein discussed. Furthermore, the symptoms observed in the plants fumigated with 80 $\mathrm{ppb} \mathrm{O}_{3}$ were similar to the symptoms present in the in situ exposed plant, which allows its validation. Vollenweider \& Günthardt-Goerg (2006) affirm that, in the validation of the damage caused by abiotic agents, a group of markers should be sought. Much attention should be paid to the localization of the symptoms in the affected cell tissues and microscopic and physiological responses as well as visible symptoms should be combined in order to achieve a better diagnosis of the stress induction agent.

In conclusion it was possible to observe in Ipomoea nil microscopic damages caused by $\mathrm{O}_{3}$ as HR-like, indicating that ozone-induced response might be detected by specific structural changes that precede the visible symptoms.

\section{Acknowledgments}

The authors thank to CNPq (National Council for Scientific and Technological Development) for the research fellow to E.S. Alves (proc. 303132/2009-4) and the scholarship to B.B. Moura. We also thank to FAPESP (The State of São Paulo Research Foundation) for the financial support (proc 02/04751-6 and proc 05/51169-9), Dr Marisa Domingos for comments and suggestions and Jéssica $B$. Nobre for $\mathrm{O}_{3}$ data.

\section{References}

CETESB. 2009. Relatório de qualidade do ar no Estado de São Paulo2004-Série Relatórios. São Paulo.

Domingos, M.; Klumpp, A. \& Klumpp, G. 1998. Air pollution impact on the Atlantic Forest at the Cubatão region, SP, Brazil. Ciência e Cultura 50: 230-236.

Epstein, E. 1975. Nutrição mineral das plantas: princípios e perspectivas. São Paulo, EDUSP.

Fernandes, A.J.; Reis, L.A.M. \& Carvalho, A. 2002. Caracterização do meio físico. In: Bicudo, D.C.; Forti, M.C. \& Bicudo, C.E.M. Parque Estadual das fontes do Ipiranga (PEFI): unidade de conservação ameaçada pela urbanização de São Paulo. Secretaria do Meio Ambiente do Estado de São Paulo, São Paulo.

Ferreira, M.L.; Nobre, J. B.; Souza, S.R. \& Domingos, M. 2007. The role of ascorbic acid in defense Ipomoea nil (L.) Roth cv. Scarlet O' Hara under the effect of air pollution. Revista Brasileira de Biociência 5: 312-314.

Gravano, E.; Giulietti, V.; Desotgiu, R.; Bussotti, F.; Grossoni, P.; Gerosa, G. \& Tani, C. 2003. Foliar response of an Ailanthus altissima clone in two sites with different levels of ozone-pollution. Environmental Pollution 121: 137-146.

Günthardt-Goerg, M.S. \& Vollenweider, P. 2007. Linking stress with macroscopic and microscopic leaf response in trees: New diagnostic perspectives. Environmental Pollution 147: 467-488.

Günthardt-Goerg, M.S.; McQuattie, C.J.; Maurer, S. \& Frey, B. 2000. Visible and microscopic injury in leaves of five deciduous tree species related to current critical ozone levels. Environmental Pollution 109: 489-500.

Günthardt-Goerg, M.S.; McQuattie, C.J.; Scheidegger, C.; Rhiner, C. \& Matyssek, R. 1997. Ozone-induced cytochemical and ultrastructural changes in leaf mesophyll cell walls. Canadian Journal of Forest Research 27: 453-463. 
Klumpp, A.; Ansel, W.; Klumpp, G. \& Fomini, A. 2001. Um novo conceito de monitoramento e comunicação ambiental: a rede européia para a avaliação da qualidade do ar usando plantas bioindicadoras (EuroBionet). Revista Brasileira de Botânica 24: 511-518.

Krupa, S.; McGrath, M.T.; Andersen, C.P.; Booker, F.L.; Burkey, K.O.; Chappelka, A.H.; Chevone, B.I.; Pell, E.J. \& Zilinskas, B.A. 2001. Ambient ozone and plant health. Plant Disease 85: 4-12.

Kubínová, L. 1994. Recent stereological methods for measuring leaf anatomical characteristics: estimation of the number and sizes of stomata and mesophyll cell. Journal of Experimental Botany 45: 119-127.

Lersten, N.R. \& Curtis, J.D. 1988. Secretory reservois (ducts) of two kinds in giants ragweed (Ambrosia trifida; Asteraceae). American Journal of Botany 75: 1313-1323.

Niderman, T.; Genetet, B.; Bruyère, T.; Gees, R.; Stintzi, A.; Legrand, M.; Fritig, B. \& Mösinger, E. 1995. Pathogenesis-related PR-1 proteins are antifungal (isolation and characterization of three 14-kilodalton proteins of tomato and of a basic PR-1 of tobacco with inhibitory activity against Phytophthora infestans). Plant Physiology 108: 17-27.

Nouchi, I. \& Aoki, K. 1979. Morning Glory as a photochemical oxidant indicator. Environmental Pollution 18: 289-303.

Nouchi, I. \& Toyama, S. 1988. Effects of ozone and peroxyacetyl nitrate on polar lipids and fatty acids in leaves of Morning Glory and Kidney Bean. Plant Physiology 87: 638-646.

Novak, K.; Skellya, J.M.; Schaub, M.; Kräuchi, N.; Hug, C.; Landolt, W. \& Bleuler, P. 2003. Ozone air pollution and foliar injury development on native plants of Switzerland. Environmental Pollution 125: 41-52.

O'Brien, T.P.; Feder, N. \& McCully, M.E. 1964. Polychomatic staining of plant cell wall by toluidine blue O. Protoplasma 59: 368-372.
Rao, M.V.; Koch, J.R. \& Davis, K.R. 2000. Ozone: a tool for probing programmed cell death in plants. Plant Molecular Biology 44: 345-358.

Reig-Armiñana, J.; Calatayud, V.; Cerveró, J.; García-Breijo, F.J.; Ibars, A. \& Sanz, M.J. 2004. Effects of ozone on the foliar histology of the mastic plant (Pistacia lentiscus L.). Environmental Pollution 132: 321-331.

Sandermann, H.; Ernst, D.; Heller, W. \& Langebartels, C. 1998. Ozone: an abiotic elicitor of plant defence reactions. Trends Plant Science 3: $47-50$.

Schraudner, M.; Langebartels, C. \& Sandermann, H. 1997. Changes in the biochemical status of plant cells induced by the environmental pollutant ozone. Physiologia Plantarum 100: 274-280.

Souza, S.R. \& Pagliuso, J.D. 2008. Design and assembly of an experimental laboratory for the study of atmosphere-plant interactions in the system of fumigation chambers. Environmental Monitoring Assessment 158: 243-249.

VDI. 2003. Verein Deutscher Ingenieure Biological measuring techniques for the determination and evaluation of effects of air pollutants on plants (bioindication). Determination and evaluation of the phytotoxic effects of photooxidants. Method of the standardized tobacco exposure. VDI 3957/6. VDI/DIN Berlin: Handbuch Reinhaltung der Luft, Vol. 1a, Beuth.

Vollenweider, P. \& Günthardt-Goerg, M.S. 2006. Erratum to "Diagnosis of abiotic and biotic stress factors using the visible symptoms in foliage" [Environ. Pollut. 137 (2005) 455e465]*. Environmental Pollution 140: $562-571$.

Vollenweider, P.; Ottiger, M. \& Günthardt-Goerg, M.S. 2003. Validation of leaf ozone symptoms in natural vegetation using microscopical methods. Environmental Pollution 124: 101-118. 